\title{
Rheological behavior and color stability of anthocyanins from Merlot (Vitis vinifera L.) and Bordô (Vitis labrusca L.) grapes in a jam model system
}

\author{
Comportamento reológico e estabilidade de antocianinas de uvas Merlot (Vitis vinifera L.) \\ e Bordô (Vitis labrusca L.) em sistema modelo de geléia
}

\author{
Ana Paula FALCÃO ${ }^{1}$, Eduardo Sidinei CHAVES $^{1}$, Leila Denise FALCÃO ${ }^{1}$, Cony GAUCHE ${ }^{1}$, \\ Pedro Luiz Manique BARRETO ${ }^{1}$, Marilde Terezinha BORDIGNON-LUIZ ${ }^{1 *}$
}

\begin{abstract}
Anthocyanins are the pigments responsible for the color of most red grapes and are easily degraded following various reaction mechanisms affected by oxygen, enzymes, $\mathrm{pH}$, and temperature among other variables. In this study, a jam model system was developed using Merlot and Bordo grape extracts and polysaccharides (xanthan and locust bean gums) and different temperatures $\left(45,55\right.$ and $65^{\circ} \mathrm{C}$ ). The stability of the anthocyanin pigments and the rheological behavior of the jam model system were studied. For the determination of the stability, the half-life time and first-order reaction rate constants for the anthocyanin pigments were calculated. The rheological behavior was determined through the Power law model. The jam model system produced using a temperature of $45^{\circ} \mathrm{C}$ showed the best results for the anthocyanin half-life time. The first-order reaction rate constants for the 45,55 , and $65^{\circ} \mathrm{C}$ treatments were not significantly different among each other $(\mathrm{p}>0.05)$. It was observed that with an increase in the jam model system temperature there was an increase in the index of consistency.

Keywords: Vitis vinifera L.; Vitis labrusca L.; anthocyanin; xanthan gum; rheological behavior.
\end{abstract}

\section{Resumo}

As antocianinas, pigmentos responsáveis pela cor vermelha das uvas, são facilmente degradadas por vários mecanismos de reação, através da ação do oxigênio, enzimas, $\mathrm{pH}$ e temperatura, entre outras variáveis. Neste trabalho, um sistema modelo de geleia foi desenvolvido utilizando extrato de uva das variedades Bordô e Merlot e polissacarídeos (gomas xantana e locusta) em diferentes temperaturas $\left(45,55\right.$ e $\left.65^{\circ} \mathrm{C}\right)$. A estabilidade dos pigmentos antociânicos e o comportamento reológico foram estudados. Para a determinação da estabilidade, calculou-se o tempo de meia-vida $(\mathrm{t} 1 / 2)$ e a constante velocidade de reação (primeira ordem) (k). Para o comportamento reológico, as constantes foram determinadas utilizando-se o modelo matemático Power law. O sistema modelo desenvolvido que utiliza a temperatura de $45^{\circ} \mathrm{C}$ mostrou os melhores resultados para o $\mathrm{t}^{1 / 2}$ das antocianinas. Os valores de $\mathrm{k}$ para os tratamentos 45,55 e $65^{\circ} \mathrm{C}$ não foram significativos $(\mathrm{p}>0,05)$. Observou-se que com o aumento da temperatura de desenvolvimento do sistema modelo de geleia houve um aumento no índice da consistência.

Palavras-chave: Vitis vinifera L.; Vitis labrusca L.; antocianina; goma xantana; comportamento reológico.

\section{Introduction}

Color is an important factor in the consumers' choice of food products. It is one of the most important characteristics used to define the quality of food and has a decisive influence on the acceptance by the consumer (BLENDFORD, 1995; HENDRY and HOUGHTON, 1996).

The replacement of synthetic colorants with natural ones as food additives has substantially increased worldwide and anthocyanins are considered an attractive option for use in foods due to their bright and attractive colors. Also, these pigments display a remarkable number of biochemical and pharmacological activities and many of their pharmacological properties have been correlated to the scavenging ability of oxygen-generated free radicals and to the inhibition of lipid peroxidation (TSUDA et al., 1994; SATUÉ-GRACIA;
HEINONEN; FRANKEL, 1997); thus, the incorporation of anthocyanins into a variety of food systems is desirable.

Anthocyanins are a group of well-known water-soluble pigments, which contribute significantly to the red-blue coloration of many flowers, fruits, and vegetables. These pigments are glycosides of polyhydroxy and polymethoxy derivatives of the 3,5,7,3-tetrahydroxyflavylium cation and are classified as flavonoids. An anthocyanin molecule comprises an aglycone or anthocyanidin moiety, which is glycosylated in its natural state by one or more sugars. The electron deficiency of the flavylium cation makes the free aglycones (anthocyanidins) highly reactive and instable and they do not occur naturally (MAZZA; MINIATI, 1993).

Recebido para publicação em $7 / 2 / 2008$

Aceito para publicação em 28/10/2008 (003202)

${ }^{1}$ Departamento de Ciência e Tecnologia de Alimentos, Programa de Pós-graduação em Ciência dos Alimentos, Universidade Federal de Santa Catarina,

Rod. Admar Gonzaga, 1346, CEP 88034-001, Florianópolis - SC, Brazil, E-mail: bordign@cca.ufsc.br

${ }^{*}$ A quem a correspondência deve ser enviada 
Grape anthocyanins are based on five aglycones that differ according to the substitution radicals in the B ring. They are found exclusively as 3-glycosides in Vitis vinifera varieties, and as 3,5-diglycosides in American species and hybrid varieties (V. labrusca, V. riparia, V. ruprestris, among others) (HEREDIA et al., 1998). The anthocyanin content of grapes is between 30 and $750 \mathrm{mg} \cdot 100 \mathrm{~g}^{-1}$ and, as with other plant material, it varies greatly according to the cultivar, vintage, and environmental factors (BRIDLE; TIMBERLAKE, 1996).

The difficulties encountered when using these pigments in the food industry result in low stability since it is highly dependent on the processing conditions such as $\mathrm{pH}$, light, oxygen, enzymes, and temperature, which significantly affect the anthocyanin color degradation (MARKAKIS, 1982).

The traditional jam production process uses pectin as the gelation agent, which needs high temperatures for the gel formation. Various studies have demonstrated that an increase in temperature is the main responsible factor for the loss of color of these pigments (BORDIGNON-LUIZ et al., 2007; GRIS et al., 2007; FALCÃO et al., 2004; KIRCA; CEMEROGLU, 2003; MORAIS etal., 2002;DYRBY;WESTERGAARD;STAPELFELDT, 2001; BROUILLARD; DUBOIS, 1977).

Polysaccharides are widely used in the food industry for their rheological properties. Xanthan is a microbial polysaccharide produced by aerobic fermentation of Xanthomonas campestris. It is widely used as a food gum because of the following important characteristics: high solution viscosity at low concentrations (HIGIRO; HERALD; ALAVI, 2006), solubility and stability in acidic systems, and interaction with other gums. Xanthan shows synergistic interactions with other polysaccharides of the galactomannan family leading to an increase in viscosity and gel formation (KAYACIER; DOGAN, 2006; RAMÍREZ et al., 2002; FENNEMA, 2008). Locust bean gum is a polysaccharide of the galactomannan family, a mucilage from the seed endosperm of the carob tree Ceratonia siliqua L., and consists of a main chain of $\beta$-D-mannopyranosyl units joined by $(1 \rightarrow 4)$ bonds with single-unit $\alpha$-D-galactopyranosyl branches (DEA and MORRISON, 1975). The synergistic interaction between xanthan and locust bean gums in diluted solution has been confirmed by Higiro, Herald, Alavi (2006).

In the food industry, the production of jelly and jam is important since they are highly lucrative products and offer an alternative use of grapes with low potential in enology (GASPAR; LAUREANO; SOUSA, 1998). Reliable rheological data on these products are essential for the design, process quality control, sensory assessment, stability and consumer acceptance (ABUJDAYIL; AL-MALAH; ASOUD, 2002; RAO, 1999).

Changes in consumer alimentary habits have led to the evolution of naturally colored food products. The development of a jam model system using low temperatures aiming at the preservation of the natural color of the grapes and other factors such as the flavor and functional properties, is also consistent with these trends. The objectives of this study were to determine the stability of anthocyanins extracted from Merlot (Vitis vinifera L.) and Bordô (Vitis labrusca L.) grapes and the rheological behavior of a jam model system using different manufacturing temperatures $\left(45,55\right.$, and $\left.65^{\circ} \mathrm{C}\right)$.

\section{Materials and methods}

\subsection{Materials}

The study was carried out with red Merlot (Vitis vinifera L.) and Bordô (Vitis labrusca L.) grapes from a 2004 harvest, which were provided by an agricultural research center (EPAGRI), from the Experimental Stations of São Joaquim (at $1415 \mathrm{~m}$ ASL) and Videira (at $774 \mathrm{~m} \mathrm{ASL}$.$) , respectively, in the state of$ Santa Catarina, Brazil.

The samples were washed under running water and treated in a solution of sodium hypochlorite $(200 \mathrm{ppm})$. The whole fruits were weighed on an analytical scale (Sartorius AG, Gottingen, Germany), frozen in a plate freezer (Frigostrella, São Paulo, Brazil), and stored at $-18 \pm 2{ }^{\circ} \mathrm{C}$. Polysaccharides xanthan (Kelko, CA, USA) and locust bean (Kerry ${ }^{\circ}$ - Brazil), potassium sorbate, fructose and absolute ethanol (Vetec ${ }^{\circ}$ - Brazil), citric acid monohydrate (Nuclear ${ }^{\curvearrowleft}$ - Brazil) and aspartame (commercial) were used. All the other reagents were of analytical grade.

\subsection{Methods}

\section{Extraction and stability of anthocyanin} pigments in a jam model system

The grape extract was obtained using $100 \mathrm{~g}$ of grapes, which were mashed and transferred to Becker cups with the aid of $20 \mathrm{~mL}$ of $6 \% \mathrm{~m} / \mathrm{v}$ citric acid solution at $\mathrm{pH} 3.0 \pm 0.2(\mathrm{pH}$ meter MP 220 Metler-Toledo). The samples were maintained at $70 \pm 2{ }^{\circ} \mathrm{C}$ in a thermostatic water bath (De Leo, Porto Alegre - RS, Brazil) for 6 minutes. The extract obtained was filtered through a Whatman $n^{\circ} 2$ (Bedford, MA) filter. The determination of total soluble solids ( $\left.{ }^{\circ} \mathrm{Brix}\right)$ in the grape extracts was carried out in an Abbe refractometer (to $25^{\circ} \mathrm{C}$ ).

The gelating agent used to obtain the jam model system was a combination of xanthan (Kelko, CA, the USA) $(0.70 \% \mathrm{~m} / \mathrm{v})$ and locust bean (Kerry, Brazil) $(0.20 \% \mathrm{~m} / \mathrm{v})$ gums. Other components were: fructose (Vetec, Rio De Janeiro, Brazil), aspartame (commercial), citric acid (up to pH 3.0) (Nuclear, Brazil), and potassium sorbate $(0.5 \%)$.

In order to evaluate the influence of the temperature used to obtain the jam model system on the stability of the anthocyanin extracts, three temperatures were applied 45 , 55 , and $65{ }^{\circ} \mathrm{C}$ (treatments 45,55 and 65 , respectively). The samples were maintained at room temperature $\left(23 \pm 3^{\circ} \mathrm{C}\right)$ for 384 hours under fluorescent light (40 W lamp, 2,500 lumens). The stability of the anthocyanin pigments in the jam model systems was studied through the absorption spectra of the samples monitored by UV-VIS absorption spectrophotometry in the visible wavelength range of 400 to $700 \mathrm{~nm}$, at regular time intervals, until $60 \%$ or more of the pigment was degraded. A Hitachi U2010 spectrophotometer (Tokyo, Japan) with a $10 \mathrm{~mm}$ optical path quartz cell was used. 
For the study of the stability of anthocyanin pigments as a function of time in the jam model system, $2 \mathrm{~g}$ of sample were added to $10 \mathrm{~mL}$ of ethanol and then centrifuged at $5,700 \mathrm{~g}$ (Janetzki K-24, Germany) for 30 minutes. The supernatant was filtered through a Whatman No. 2 (Bedford, MA) filter. The absorbance was read at the wavelength of maximum absorption for the anthocyanin pigments in the visible part of the spectrum $(540 \mathrm{~nm})$. The first-order reaction constant ( $\mathrm{k}$ ) (Equation 1) and the half-life time $\left(\mathrm{t}_{1 / 2}\right)$ (Equation 2) were calculated according to Kirca and Cemeroglu (2003) using the equations below:

$\ln \left(A_{t} / A_{0}\right)=-k \times t$

$t_{1 / 2}=-\ln 0.5 \times k^{-1}$

where,

$\mathrm{t}=$ time (hours);

$A_{t}=$ final absorbance ("time $t$ "); and

$\mathrm{A}_{0}=$ initial absorbance ("time zero").

\section{Rheological measurements}

The rheological behavior of the jam model system during treatments 45,55 , and 65 was investigated using a Brookfield rotational rheometer (Brookfield Engineering Laboratories model DV III Ultra, Stoughton, MA, USA) with a concentric cylinder (spindle ULA) and collected using a Rheocalc ${ }^{\circledR} 32$ software version 2.5 (Brookfield Engineering Laboratories, Inc., Middleboro, MA02346, USA). The rheometer was thermostatically controlled by a water circulator (TECNAL model TE-184, SP, Brazil) at $23 \pm 2{ }^{\circ} \mathrm{C}$. The samples remained at rest for 15 minutes to ensure stability before being loaded into the viscosimeter. Apparent viscosity measurements as a function of shear rate were obtained through the linear increase in the shear rate from 7.0 to $155.0\left(\mathrm{~s}^{-1}\right)$ in the initial 75 minutes with a return to $7.0 \mathrm{~s}^{-1}$ in the following 75 minutes. The data were evaluated using Origin ${ }^{\oplus}$ software version 6.0 (Microcal Software Inc., Northampton, MA01060, USA).

The graph of apparent viscosity $(\eta)$ versus shear rate $(\gamma)$ becomes linear when plotted on logarithmic coordinates (RAO, 1999), and the Power law model could be applied to describe the pseudoplastic (shear-thinning) and dilatant (shearthickening) fluid data (MANICA; DE BORTOLI, 2004).

The Power law model (Equation 3) is applied to a reasonable number of fluids that show non-Newtonian behavior (JIE and KE-QIN, 2006).

$\eta=K(\gamma)^{n-1}$

where,

$$
\begin{aligned}
& \eta=\text { apparent viscosity }(\text { Pa.s }) \\
& K=\text { consistency index }\left(\text { Pa. } \mathrm{s}^{\mathrm{n}}\right) ; \\
& \gamma=\text { shear rate }\left(\mathrm{s}^{-1}\right) ; \text { and } \\
& \mathrm{n}=\text { flow behavior index. }
\end{aligned}
$$

\section{Statistical analysis}

The first-order reaction constant $(\mathrm{k})$, half-life time $\left(\mathrm{t}_{1 / 2}\right)$, and rheological parameters of the samples under different treatments were studied by means of analysis of variance (ANOVA/ MANOVA) with the STATISTICA software version 6.0 (2001) (StatSoft, Inc., Tulsa, OK, USA). When a significant difference was detected at the 95\% significance level, the Tukey test was applied. The experiments were carried out in triplicate.

\section{Results and discussion}

\subsection{Stability study of anthocyanins in a jam model system}

An anthocyanin stability study was carried out with Merlot and Bordô grapes in a jam model system. The total solids content of the Merlot and Bordô grapes was determined as 19 and $18^{\circ} \mathrm{Brix}$, respectively. Tables 1 and 2 show the values for the first-order reaction rate constants $(\mathrm{k})$ and half-life time $\left(\mathrm{t}_{1 / 2}\right)$ of the anthocyanin pigments in the jam model system, employing temperatures of 45,55 , and $65^{\circ} \mathrm{C}$.

Analyzing the $t_{1 / 2}$ values for the anthocyanins, it is clear that the pigments extracted from Merlot and Bordô grapes have a greater stability $(\mathrm{p}<0.05)$ on applying thermal treatment at $45^{\circ} \mathrm{C}$ (Table 1 and 2). For the treatment at $65^{\circ} \mathrm{C}$, the pigments extracted from Bordô grapes had a greater stability than those extracted from Merlot grapes ( $\mathrm{p}$ 0.05). For the other two temperatures, there was no significant difference between the Merlot and Bordô grape pigment stabilities ( $\mathrm{p}>0.05)$.

For jam model systems manufactured with the crude extract from Merlot grapes, the $t_{1 / 2}$ values of the samples submitted to treatment 55 show no significant statistical difference for

Table 1. Half-life time $\left(\mathrm{t}_{1 / 2}\right)$ and first-order reaction rate constants $(\mathrm{k})$ for anthocyanin pigment in jam model system obtained from Merlot grapes.

\begin{tabular}{ccc}
\hline Treatments & $\mathrm{t}_{1 / 2}$ (hours) & $\mathrm{k}\left(\mathrm{s}^{-1}\right)$ \\
\hline 45 & $746^{\mathrm{a}}$ & $0.9 \times 10^{-3 \mathrm{a}}$ \\
55 & $476^{\mathrm{a}, \mathrm{b}}$ & $1.5 \times 10^{-3 \mathrm{a}, \mathrm{b}}$ \\
65 & $290^{\mathrm{b}}$ & $2.5 \times 10^{-3 \mathrm{a}}$ \\
\hline
\end{tabular}

All results correspond to the mean of values obtained in triplicate.

a,b Different letters in a same column indicate that the values differ significantly at the $5 \%$ level (Tukey Test).

Table 2. Half-life time $\left(\mathrm{t}_{1 / 2}\right)$ and first-order reaction rate constants $(\mathrm{k})$ for anthocyanin pigment in jam model system obtained from Bordô grape ss.

\begin{tabular}{ccc}
\hline Treatment & $\mathrm{t}_{1 / 2}$ (hours) & $\mathrm{k}^{\left(\mathrm{s}^{-1}\right)}$ \\
\hline 45 & $808^{\mathrm{a}}$ & $0.8 \times 10^{-3 \mathrm{a}}$ \\
55 & $614^{\mathrm{b}}$ & $1.1 \times 10^{-3 \mathrm{~b}}$ \\
65 & $478^{\mathrm{c}}$ & $1.2 \times 10^{-3 \mathrm{c}}$ \\
\hline
\end{tabular}

All results correspond to the mean of values obtained in triplicate.

a,b,c Different letters in a same column indicate that the values differ significantly at the 5\% level (Tukey Test). 
treatments 45 and 65 ( $p>0.05)$. Treatments 45 and 65 showed statistically significant differences for the $t_{1 / 2}$ values $(p<0.05)$; treatment 45 conferred greater stability on the anthocyanin pigments, with a longer $t_{1 / 2}$ value. These results are in agreement with Kirca; Cemeroglu (2003), who investigated, among other factors, the influence of different temperature ranges on the thermal stability of anthocyanins from blood and concentrate orange juice at concentrations of $11.2,45$, and $69{ }^{\circ}$ Brix. The kinetic parameters showed that anthocyanin degradation increased with an increase in temperature. The $t_{1 / 2}$ values for anthocyanins of a $45^{\circ}$ Brix concentrate were 55.7, 9.7, and $2.1 \mathrm{~h}$ at 5,20 , and $37^{\circ} \mathrm{C}$, respectively, while these values decreased to $3.4,1.3$, and 0.7 hours when the temperatures were raised to 70,80 , and $90^{\circ} \mathrm{C}$, respectively.

For the jam model system produced with the crude extract from Bordo grapes, the $t_{1 / 2}$ values of the samples submitted to treatment 55 showed no significant statistical difference from those submitted to treatment 65 ( $p>0.05$ ). However, for treatment 45 there was a significant difference in the $t_{1 / 2}$ values $(\mathrm{p}<0.05)$, indicating greater stability of the anthocyanin pigments; with a higher $t_{1 / 2}$ value and a lower $k$ value for the jam model system. The processing temperature increase resulted in a high degradation of the anthocyanin pigments. It is important to observe that these results were obtained under what is considered "stress" conditions for anthocyanins (light and ambient temperature of $23^{\circ} \mathrm{C}$ ).

The flavylium cation is stable at low temperatures. According to Brouillard, Dubois (1977) an increase in temperature leads to the breaking of the flavylium cation ring, which is converted into the chalcone form, of yellow color. Considering the anthocyanin stability during the jam storage, temperatures of $45^{\circ} \mathrm{C}$ conferred higher stability in relation to the other temperatures evaluated (Tables 1 and 2). Our results are consistent with those reported by Watanabe et al. (1991) who studied a new method for producing non-heated jam samples and verified that the low processing temperature maintained the jam color and fresh flavor properties. Using freeze concentration and high-pressure sterilization, these authors proposed a method for producing non-heated jam. Jam color properties observed in the nonheated samples and those subjected to conventional heating were: brightness ( $L$ value) 7.8 and 7.2, red ( $a$ value) 15.2 and 13.4, and yellow ( $b$ value) 5.8 and 5.4, respectively.

\section{Rheological measurements}

The flow behavior of the model system produced with extracts from Merlot and Bordô grapes was evaluated. Apparent viscosity values as a function of increasing shear rate for the different jam model systems obtained using 45 , 55 , and $65^{\circ} \mathrm{C}$ are shown in Figure 1. The flow curves for these systems demonstrated behavior characteristic of nonNewtonian fluids and pseudoplastic rheology, as also reported by Watanabe et al., 1991, who observed this behavior in the manufacture of non-heated strawberry jam samples.

The samples have pseudoplastic flow properties, which indicates that their viscosity decreases as the shear rate increases (Figures 1a and 1b). Xanthan gum produces highly viscous solutions in low concentrations. It is a non-gelling polysaccharide that can exist in solution in a rigid, ordered, chain conformation (RAMÍREZ et al., 2002).

Xanthan gum is known for its strong interactions with galactomanans such as locust bean gum, which results in gel formation and, as a consequence, increases the viscosity and quality of food products (HIGIRO; HERALD; ALAVI, 2006; PAI; KHAN, 2002).

Solutions comprising xanthan gum have more evident pseudoplastic behavior than other solutions with different gums due to its semi-rigid conformation (MANDALA; SAVVAS; KOSTAROPOULOS, 2004).

Similar behavior was reported by Kayacier, Dogan (2006), who prepared solutions with different gums, including xanthan and guar, and determined the rheological properties of these solutions using the Power law model. These authors found that the apparent viscosity decreased with an increase in the shear rate.

Our results are also in agreement with XUEWU et al., (1994), who studied the rheological behavior of xanthan gum at different
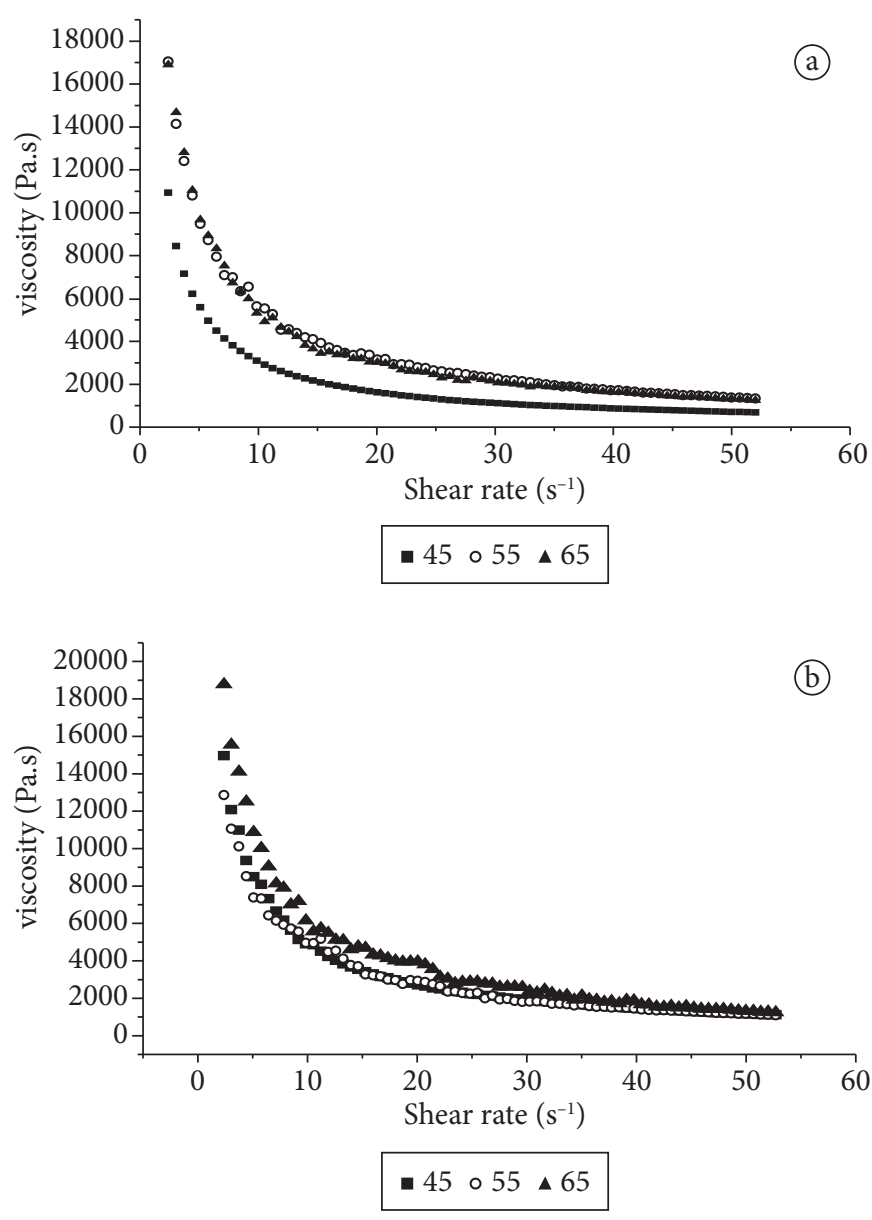

Figure 1. Effect of the shear rate on the apparent viscosity of the jam model systems manufactured with red grapes of the Merlot (Vitis vinifera L.) (A) and Bordô (Vitis labrusca L.) (B) varieties at 45; 55, and $65^{\circ} \mathrm{C}$. 
temperatures $\left(20-100{ }^{\circ} \mathrm{C}\right)$ and concentrations $(0.3-1.3 \% \mathrm{p} / \mathrm{p})$. These authors found that viscosity decreased as the shear rate increased and the mathematical model that most adequately described the rheological behavior of the xanthan gum was the Power law.

Treatments 55 and 65 with the Merlot (Vitis vinifera L.) grape extract showed a greater apparent viscosity in the range of shear rate studied when compared with treatment 45 (Table 3). The apparent viscosities of systems 55 and 65 showed no statistically significant differences in relation to the samples produced with the extract of Bordô grapes (Vitis labrusca L.). It was observed that the consistency index values of the systems obtained at $65{ }^{\circ} \mathrm{C}$ were significantly higher than those of the other treatments.

The Power law rheological parameters of the jam model system are shown in Table 3. The increase in the consistency index is proportional to the temperature increase suggesting that an increase in temperature stabilized the three dimensional network formed by the polysaccharide molecules present in the systems (xanthan and locust bean gums) producing a strong gel.

The consistency index of the jam models at 55 and $65^{\circ} \mathrm{C}$ may be due to synergic interaction between the xanthan and locust bean gums. Tako, Asato, Nakamura 1984, suggested that the interaction occurs between xanthan side chains and the locust bean gum backbone as in a lock-and-key model, in which one xanthan chain could associate with one, two, or more locust bean molecules. For this interaction, a rearrangement of the xanthan at temperatures exceeding the helix-coil transition temperature is necessary for binding to occur (CAIRNS et al., 1987). This conformational transition corresponds to a helix-coil transition of the backbone with a simultaneous release of the lateral

Table 3. Power law model parameters of jam model system.

\begin{tabular}{ccccc}
\hline Jam Model System & Treatment & $\mathrm{K}\left(P a \cdot \mathrm{s}^{\mathrm{n}}\right)\left(.10^{2}\right)$ & $\mathrm{n}$ & $\mathrm{R}$ \\
\hline Merlot grape extract & 45 & $240^{\mathrm{a}}$ & 0.10 & 0.99 \\
& 55 & $382^{\mathrm{b}}$ & 0.16 & 0.99 \\
& 65 & $364^{\mathrm{b}}$ & 0.19 & 0.99 \\
Bordô grape extract & 45 & $295^{\mathrm{a}}$ & 0.14 & 0.99 \\
& 55 & $330^{\mathrm{a}}$ & 0.17 & 0.99 \\
& 65 & $366^{\mathrm{b}}$ & 0.21 & 0.99 \\
\hline
\end{tabular}

$K\left(\mathrm{~Pa} . \mathrm{s}^{n}\right)=$ consistency index, $\mathrm{n}=$ flow behavior index, $\mathrm{R}=$ linear correlation coefficient.

All results correspond to the mean of values obtained in triplicate.

a,b Different letters in a same column indicate that the values differ significantly at the $5 \%$ level (Tukey Test).

Table 4. Hysteresis data of jam model systems obtained with Merlot grape (Vitis vinifera L.) extracts.

\begin{tabular}{ccc}
\hline Jam Model System & Treatments & Hysteresis (Area) \\
\hline Merlot grape extracts & 45 & $1,170.45$ \\
& 55 & $2,323.70$ \\
& 65 & $3,716.25$ \\
\hline
\end{tabular}

chains followed by a progressive decrease in the rigidity of the (1-4)- $\beta$-D-glucan chain as the temperature increases from 40 to $60{ }^{\circ} \mathrm{C}$.

An important characteristic of the apparent viscosity/shear rate ratio is the occurrence of hysteresis, that is, the area between the downward curves (decreased shear rate) and upward curves (increased shear rate) indicating that the samples are timedependent (TÁRREGA; DURAN; CISTELL, 2004), and the greater the area, the stronger the correlation with the thixotropy of the product. The evaluation of the flow behavior of different jam model systems resulted in hysteresis proportionally to the increase in gel formation temperature. The greater interaction between these gums resulted in the formation of a gel with a firmer structure, and consequently, with greater hysteresis. This can be observed for the jam model systems obtained with Merlot grape extracts in Table 4.

\section{Conclusions}

An important factor to be considered in jam production is temperature. In this study, jam samples obtained at $45^{\circ} \mathrm{C}$ showed the best results for anthocyanin pigment half-life time, indicating that it is possible to improve the color stability using low temperatures during jam processing. However, in relation to the rheological properties we observed that the best consistency for the jam model systems was obtained at $65^{\circ} \mathrm{C}$ and the lowest consistence at $45^{\circ} \mathrm{C}$. Future research should be carried out to obtain an ideal consistency and greater anthocyanin stability.

\section{Acknowledgements}

The authors are grateful for the financial support provided by the Brazilian foundations CAPES and CNPq, and to EPAGRI (São Joaquim and Videira Experimental Stations) for kindly supplying the Merlot and Bordô grapes samples.

\section{References}

ABU-JDAYIL, B.; AL-MALAH, K.; ASOUD, H. Rheological characterization of milled sesame (tehineh). Food Hydrocolloids, v. 16, n. 1, p. 55-61, 2002.

BLENDFORD, D. Colouring consumer's perceptions. Food Ingredients and Analysis International, v. 17, n. 2, p. 10-11, 1995.

BORDIGNON-LUIZ, M. T. et al. Colour stability of anthocyanins from Isabel grapes (Vitis labrusca L.) in model systems. LWT, v. 40, n. 4, p. 594-599, 2007.

BRIDLE, P.; TIMBERLAKE, C. F. Anthocyanins as natural food colours-selected aspects. Food Chemistry, v. 58, n. 1-2, p. 103-109, 1996.

BROUILLARD, R.; DUBOIS, J. E. Mechanism of the structural transformations of anthocyanins in acidic media. Journal of the American Chemical Society, v. 99, n. 5, p. 1359-1364, 1977.

CAIRNS, P. et al. X-ray fibre-diffraction studies of synergistic binary polysaccharide gels. Carbohydrate Research, n. 160, p. 411-423, 1987.

DEA, I. C. M.; MORRISON, A. Chemistry and interactions of seed galactomannans. Advances in Carbohydrate Chemistry and Biochemistry, v. 31, p. 241-312, 1975. 
DYRBY, M.; WESTERGAARD, N.; STAPELFELDT, H. Light and heat sensitivity of red cabbage extract in soft drink model systems. Food Chemistry, v. 72, p. 431-437, 2001.

FALCÃO, L. D. et al. Stability of anthocyanins from grape (Vitis vinifera L.) skins with tannic acid in a model system. Italian Journal of Food Science, v. 16, n. 3, p. 323-332, 2004.

FENNEMA, O. R. Food Chemistry. 4 ed. Wisconsin: University of Wisconsin Madison, 2008.

GASPAR, C.; LAUREANO, O.; SOUSA, I. Production of reducedcalorie grape juice jelly with gellan, xanthan and locust bean gums: sensory and objective analysis of texture. Zeitschrift für Lebensmitteluntersuchung und-Forschung, v. A, n. 206, p. 169-174, 1998.

GRIS, E. F. et al. Caffeic acid copigmentation of anthocyanins from Cabernet Sauvignon grape extracts in model systems. Food Chemistry, v. 100, n. 3, p. 1289-1296, 2007.

HENDRY, G. A.; HOUGHTON, J. D. Natural Food Colourants. Glaslow: Backie Academic and Professional, 1996. 348 p.

HEREDIA, F. J. et al. Chromatic characterization of anthocyanins from red grapes, pH effect. Food Chemistry, v. 63, n. 4, p. 491-498, 1998.

JIE, P.; KE-QIN, Z. Drag force of interacting coaxial spheres in viscoplastic fluids. Journal of Non-Newtonian Fluid Mechanics, v. 135, p. 83-91, 2006.

HIGIRO, J.; HERALD, T. J.; ALAVI, S. Rheological study of xanthan and locust bean gum interaction in dilute solution. Food Research International, v. 39, n. 4, p.165-175, 2006.

KAYACIER, A.; DOGAN, M. Rheological properties of some gumssalep mixed solutions. Journal of Food Engineering, v. 72, n. 3, p. 261-265, 2006.

KIRCA, A.; CEMEROGLU, B. Degradation kinetics of anthocyanins in blood orange juice and concentrate. Food Chemistry, v. 81, n. 4, p. 583-587, 2003.

MANDALA, I. G.; SAVVAS, T. P.; KOSTAROPOULOS, A. E. Xanthan and locust bean gum influence on the rheology and structure of a white model-sauce. Journal of Food Engineering, v. 64, n. 3, p. 335-342, 2004.
MANICA, R.; de BORTOLI, A. L. Simulation of sudden expansion flows for power law fluids. Journal of Non-Newtonian Fluid Mechanics, v. 121, n. 1, p. 35-40, 2004.

MARKAKIS, P. Anthocyanin as food colours. New York: Academic Press, Inc., 1982.

MAZZA, G.; MINIATI, E. Anthocyanins in Fruits, Vegetables and Grains. Boca Raton - Florida: CRC Press, 1993.

MORAIS, H. et al. Influence of storage conditions on the stability of monomeric anthocyanins studied by reversed-phase highperformance liquid chromatography. Journal of Chromatography, v. 770, n. 1, p. 297-301, 2002.

PAI, V. B.; KHAN, S. A. Gelation and rheology of xanthan/enzymemodified guar blends. Carbohydrate Research, v. 49, n. 2, p. 207-216, 2002.

RAMÍREZ, J. A. et al. Effect of xanthan and locust bean gums on the gelling properties of myofibrillar protein. Food Hydrocolloids, v. 16, n. 1, p. 11-16, 2002.

RAO, M. A. Rheology of fluid and semisolid foods: principles and applications. Gaitesburg-Aspen: [s.n.], 1999.

SATUÉ-GRACIA, M. T.; HEINONEN, M.; FRANKEL, E. N. Anthocyanins as Antioxidant on Human Low Density Lipoprotein and Lecithin-Liposome Systems. Journal Agriculture Food Chemistry, v. 45, n. 9, p. 3362-3367, 1997.

TAKO, M.; ASATO, A.; NAKAMURA, S. Rheological aspects of the intermolecular interaction between xanthan and locust bean gum in aqueous media. Agricutural and Biological Chemistry, v. 48, n. 12, p. 2995-3000, 1984.

TÁRREGA, A.; DURAN, L.; COSTELL, E. Flow behaviour of semi-solid dairy desserts. Effect of temperature. International Dairy Journal, v. 14, n. 4, p. 345-353, 2004.

TSUDA, T. et al. Antioxidative activity of the anthocyanin pigments cyanidin 3-O- $\beta$-D-glucoside and cyanidin. Journal Agriculture Food Chemistry, v. 42, n. 11, p. 2407-2410, 1994.

WATANABE, M. et al. A New Method for Producing a Non-heated Jam Sample: The Use of Freeze Concentration and High-pressure Sterilization. Agriculture Biological Chemistry, v. 55, n. 8, p. 2175-2176, 1991. 